\title{
PEDAGOGO VEIKLOS TOBULINIMO GALIMYBĖS, MOKANT ANTROSIOS UŽSIENIO (VOKIEČIŲ) KALBOS: FILMŲ UŽSIENIO KALBA ASPEKTAS
}

\author{
Doc. dr. Nijolè Čiučiulkienė
}

Aleksandro Stulginskio universitetas

Jurgita Lukienè

Kauno technologijos universitetas

\begin{abstract}
Anotacija. Europos Komisijos prioritetine tema yra europinio raštingumo (angl. European literacy) ugdymas. Raštingumas j̇vardijamas kaip pastovus dinaminis socialinis ir kultūrinis fenomenas, kuriam ịtaka daro socialiniai pokyčiai ir greitas komunikaciniu technologiju vystymasis (Walczak-Niewiadomska, A., 2015). Viena iš salygu tobulinti europinio raštingumo kompetencijas yra kalbu ìvairovés puoselejjimas. Kaip teigiama UNESCO ir Europos Komisijos dokumentuose apie užsienio kalbų mokèjima, Europos piliečiai turètu bendrauti bent dviem užsienio kalbomis (Gelünas, 2015). Intensyvejjant integracijos procesams, ugdytojui vis dažniau tenka dirbti tarptautinèse grupèse, mokyti antrosios užsienio kalbos (vokiečiu) globaliosios lingua franca (šiuo atveju anglu) kontekste, t. y. mokyti vokiečiu kalbos, kalbant angliškai. Tai didelis iššūkis užsienio kalbos mokytojams/dèstytojams, nes, siekiant veiksmingo užsienio kalbu mokymo, užsienio kalbu mokantys pedagogai turi tobulinti savo metody repertuara, vaidmenis, ugdymo turini praturtinti realiomis gyvenimo situacijomis (Leonavičienè, V., Salienè, V., 2013), todèl ypač svarbu pateikti ịdomia, aktualia, motyvuojančia užsienio kalbos mokymo(si) medžiaga, kuri papildytu gaunama informacija vaizdiniais anglu kalba vaizdiniais, komentuojamais vokiškai. Vienas iš tokiu metody yra filmu originalo kalba aktyvus žiürèjimas, taikant užduočiu j̇vairovę užsienio kalbos issisavinimui. Filmu originalo kalba efektyvumas, mokantis užsienio kalbos (Blell, Leutge, 2008), tyrinejamas atliekant pedagoginès veiklos tobulinimo tyrima (angl. action research), leidžiantị ịtraukti besimokančiuosius ị aktyvu užsienio kalbos mokymosi problemu sprendima (Cohen, M., Morrison, K., 2007). Tai atspindi kartu su besimokančiaisiais formuluojant pedagoginès veiklos tobulinimo tyrimo klausima: , Kaip galéčiau padèti anglu kalba kalbantiems besimokantiesiems tobulinti savo kalbejjimo vokiškai igūdžius, naudojant filmus originalo kalba? " Ši klausima galima traktuoti kaip mini užsienio kalbos mokymosi programa, apimančia veiklas, tokias kaip teksto originalo kalba klausymas, reikšmès interpretavimas, subtitravimo gebejjimu ugdymas, autorinio teksto ịrašo kūrimas ir kt. Atliekant pedagoginès veiklos tobulinimo tyrima, išryškèjo tokie teigiami pokyčiai: studentai teigia, kad pirmiausia patobulejo ju pirmosios užsienio kalbos (anglu) žinios, kad kartu su dèstytoja analizuodami savo vokiečiu kalbos mokymosi problemas, galejo remtis anglu kalbos mokymosi patirtimi, geriau suprato filmu, kaip užsienio kalbos mokymosi metodo, galimybes, todèl, lygindami kalbu panašumus, lengviau ìsiminè žodyną. Be to, besimokančiuju
\end{abstract}


nuomone, frazé, susijusi su vaizdu ir garsu, plètojo klausymo ir kalbejjimo igūdžius, o naudodami informacines technologijas subtitru kūrimui, aktyviai mokèsi gramatikos, rašybos ir leksikos. Besimokantieji taip pat paminejo ir trūkumus: ne visada pavykdavo išgirsti tai, kas sakoma, suprasti frazeologizmus ar idiomas.

Pagrindiniai žodžiai: antrosios užsienio kalbos mokymas(is) anglu kalba, informacinès technologijos, filmai originalo kalba, veiklos tobulinimo tyrimas.

Ivadas. Kaip teigia P. Freiras (2000), raštingumas yra ,žodžio ir pasaulio skaitymas“" arba, kitais žodžiais tariant, mokèjimas suprasti ekonomikos, kultūros, meno ženklus. Vadinasi, yra kultūrinis raštingumas, ekonominis raštingumas, meninis raštingumas ir pan. Raštingumas taip pat gali būti ịvardijamas kaip dinaminis socialinis ir kultūrinis fenomenas, kurị modeliuoja ịvairūs socialiniai pokyčiai ir greitas komunikacinių technologijų vystymasis (Walczak-Niewiadomska, A., 2015). Taigi, šiandien raštingumas yra kur kas platesnė sąvoka nei gebėjimas skaityti ir rašyti - tai pagrindinė investicija ị ateitị ir pirmas žingsnis ị naujas raštingumo formas XXI amžiuje (Bokova, I., 2016). Dabarties epocha - tai žiniu visuomenès, daugiakalbystès ir daugiakultūriškumo, kūrybingumo ir inovacijų laikas (Vaišnienè, D., Zabarskaitė, J., Rehm, G., Uszkoreit, H., 2012; Ramonienė, M., 2014; Gelūnas, A., 2015), todèl šiuolaikinis raštingumas apima klasikinio raštingumo, kalbos technologiju išmanymo, kultūrinio raštingumo ir informacinio raštingumo aspektus ir apjungia juos ị holistine raštingumo vienovę. Tokio raštingumo gebejjimus turintys jauni žmonès bus pasirenge aktyviai ir kūrybiškai dalyvauti vis spartèjančiuose šiuolaikinio gyvenimo procesuose, būti konkurencingi globalioje dabartinio pasaulio erdveje (Rehm, G., Uszkoreit, H., Dagan, I., Goetcherian, V., Dogan, M. U., Mermer, C. ir kt., 2014).

Viena iš esminių prielaidų būti raštingu holistine prasme yra užsienio kalbų mokejjimas. Palyginus su $2001 \mathrm{~m}$. Lietuvos piliečių surašymo duomenimis, $2011 \mathrm{~m}$. padaugèjo gyventojų, mokančių užsienio kalbų - 78,5 procento mokèjo vieną ar daugiau užsienio kalbų. Palyginus su 2001 m., išaugo anglų kalbą mokančių gyventojų dalis (nuo 16,9 iki 30,4 proc.). Rusų kalbą mokejjo 63 procentai gyventojų, lenkų - 8,5 procento, vokiečių - 8,3 procento. Anglų ir vokiečių kalbos išlieka populiariausios tarp jaunų gyventojų. Beveik pusė gyventojų, mokančių anglų kalbą, buvo 15-29 metų amžiaus. Kas trečias gyventojas, mokèjęs vokiečių arba prancūzų kalbą, buvo 20-34 metų.

Spartėjant globalizacijos procesams, antrosios užsienio kalbos mokymasis tarptautinėse grupėse, vartojant pirmąją užsienio kalbą (anglų), tampa neišvengiama realybe. Šios problemos sprendimas skatina kūrybiškai pažvelgti ị užsienio kalbų mokymą, akcentuojant aktyvius mokymosi metodus, priemones, ir juos įvertinti (Augustinienè, A., Čiučiulkienė, N., 2013). Vienas iš tokių metodų yra kalbų mokymasis, kaip mokomają medžiagą naudojant filmus originalo kalba, todèl šio straipsnio tyrimo objektas yra filmų originalo kalba taikymo galimybès, mokantis 
antrosios užsienio kalbos, komunikuojant pirmaja užsienio kalba. Tyrimo tikslas atskleisti filmų originalo kalba užsienio kalbos dèstyme veiksmingumą, atliekant pedagoginès veiklos tobulinimo tyrimą. Tikslui pasiekti keliami šie uždaviniai:

1. Atlikti sampratų ,europinis raštingumas“, „filmų originalo kalba naudojimas kaip metodas" mokslinès literatūros analizę.

2. Pagrịsti filmų originalo kalba naudojimo efektyvumą, atliekant pedagoginès veiklos tobulinimo tyrimą.

3. Atlikti studentų požiūrių ị filmų originalo kalba naudojimo turinio analizę.

Atliekant tyrimą, naudoti šie mokslinio tyrimo metodai:

- mokslinès literatūros analizé;

- dokumentų analizè;

- pedagoginès veiklos tobulinimo tyrimas;

- studentų požiūrių i filmų originalo kalba naudojimą (angl. content) turinio analizè.

Straipsnį sudaro trys dalys: pirmojoje dalyje atliekama mokslinès literatūros analizè, kurios tikslas - išanalizuoti europinio raštingumo, filmų originalo kalba naudojimo kaip metodo sampratas. Antroji dalis skirta pedagoginès veiklos tobulinimo tyrimo analizei, išryškinant filmų originalo kalba naudojimo efektyvumą, mokantis vokiečių kalbos, kada dèstytojas ir besimokantieji komunikuoja angliškai. Trečioji dalis skirta tyrimo rezultatų aptarimui ir diskusijai. Straipsnio pabaigoje pateikiamos išvados.

Tyrimo metodai. Duomenų rinkimo metodai: mokslinès literatūros analizè, studentų apklausa raštu. Duomenų analizès metodai: fenomenografinè tiriamuju požiūrių turinio analizè.

\section{Pagrindinè straipsnio dalis}

\section{Sampratų „,europinis raštingumas“, „filmų originalo kalba naudojimas kaip metodas" analizè}

Raštingumas siejamas su pačiomis ịvairiausiomis šiandienos gyvenimo aktualijomis. Jis apima skirtingas gyvenimo sritis. Shelly Stagg Petreson, Daphne Heywood (2007), Jennifer Rowsell (2013), Teresa Cremin (2015) raštingumo sąvokos įvairovę sieja su mokymo ir mokymosi socialinès ir technologinès aplinkos kaita, jos multimodalumu. Raštingumas įvardijamas kaip pastovus dinaminis, socialinis ir kultūrinis fenomenas, kuriam įtaką daro socialiniai pokyčiai ir greitas komunikacinių technologijų vystymasis, todèl raštingumo sampratoje galima išskirti tokius teminius aspektus:

- raštingumas švietimo institucijose ir už jų ribų: nuo ankstyvojo amžiaus iki senatvès;

- mokymas mokyti: raštingumo mokymas; 
- daugiakalbiškumas (angl. multilingualism), pliuralizmas, literatūra skirtingose kultūrose;

- vaikų, paauglių ir suaugusiųjų literatūra: tradicija, nauji žanrai, naujos medijos;

- raštingumo skatinimas socialinèse svetainèse: bibliotekos, skaitytojų grupès, konkursai ir pan.;

- raštingumas: prieinamumas, lygybè/nelygybè ir negalia;

- daugiaraštingumas (angl. multiliteracies): tekstai, kontekstai, koncepcijos, praktika, tapatybè, pilietybè.

Holistinè raštingumo samprata skatina ir holistinị raštingumo mokymą, todèl šiandienos paskaitoje/pamokoje dėstytojas/mokytojas turètų būti šiuolaikiškas, inovatyvus, gebantis komunikuoti keliomis užsienio kalbomis, motyvuotas naudoti technologijas, taikyti lanksčius ir įvairius mokymo(si) metodus, kurie žadintų ne tik tradicinị besimokančiojo raštingumo tobulinimą, bet ir vizualinio raštingumo ugdymą, kuris skatintų smalsumą, kūrybingumą ir motyvaciją mokytis užsienio kalbų (Čiučiulkienè, N., 2004; Cremin, T., 2015), naudojantis medijų ir technologijų galimybėmis. Šiame kontekste išryškèja televizijos ir interneto vaidmuo. Televizija ir internetas sudaro sąlygas ịsitraukti ị originalią kalbinę aplinką ir mokytis užsienio kalbos, stebint ịvairaus žanro filmus, serialus, televizijos šou. Žiniu pranešimai taip pat puiki priemonè ir būdas mokytis kalbų.

Atskirai reikètų akcentuoti filmų originalo kalba vaidmenį, mokant antrosios užsienio kalbos tarptautinèje grupejje, kai, komunikuojant angliškai, mokomasi vokiečių kalbos. Filmas yra kino ar televizijos kūrinys; meninị vaizdą sudaro filme užfiksuoti erdviniai vaizdai (suvaidintos scenos, nuotraukos iš natūros, piešiniai) ir garsai (kalba, muzika). Filmų ypatinga savybe yra išsamus komunikacinès situacijos vaizdavimas (Faulstich, W., 2002). Vaizdo ir garso dinaminè kaita leidžia besimokantiesiems įdèmiau stebèti ir geriau suprasti situaciją. Jie gali vienu metu stebèti ir girdèti filmo herojus, nustatyti jų amžių, lytį, santykius tarp dalyvių ir t. t. Matydami aprangą, gali nustatyti jų socialinị statusą arba atpažinti, ką jie šiuo metu veikia, iš mimikos, gestų suprasti nuotaiką ir jausmus. Filmo demonstravimas turètų sudominti besimokantijị, net jei jo kalbos žinios yra ribotos.

Dabartinejje paskaitoje filmas nepakankamai vertinamas kaip užsienio kalbos mokymosi metodas. Vis dar gajus stereotipas, kad filmas demonstruojamas tam, kad užpildytų likusị laiką (Hahn, N., 2015), tačiau didaktiškai apgalvotas darbas su video medžiaga gali praturtinti paskaitą metodine ir turinio prasme. Filmas paskaitos metu reiškia aktyvų mokymąsi, kreipiantị asmenybę komunikacijos emancipacijos kryptimi (Čiučiulkienė, N., Bankauskienė, N., 2015). Siekdamas komunikacijos užsienio kalba emancipavimo, pedagogas, dėstantis užsienio kalbą, turètu kryptingai tobulinti savo veiklą, analizuodamas savo ugdytinių kalbos mokymosi poreikius, juos atitinkamai derindamas su savo desstymo metodų repertuaru, nuolat keldamas sau klausimą: „Kaip galečiau savo ugdytiniams padèti geriau įsisavinti užsienio kalbą?“ Šis klausimas formuoja mini užsienio kalbos mokymosi progra- 
mą, kurios esmè - pedagoginès veiklos tobulinimo tyrimas (angl. action research), leidžiantis tiek ugdytojui, tiek besimokantiesiems aktyviai dalyvauti užsienio kalbos mokymosi procese, visiems įsitraukiant ị kylančiu problemų sprendimą (Cohen, L., Manion, L., Morrison, K., 2007).

\section{Filmụ originalo kalba efektyvumo nustatymas, atliekant pedagoginès veiklos tobulinimo tyrimą}

\subsection{Pagrindinès pedagoginès veiklos tobulinimo tyrimo nuostatos, taikant filmus originalo kalba antrosios užsienio kalbos mokyme anglu kalba}

Apibūdinant pedagoginès veiklos tobulinimo tyrimą, vertètų remtis V. Koshy (2010, p. 1) teiginiu, apibrèžiančiu veiklos tyrimą kaip metodą, naudojamą mokymo(si) veiklų kokybei gerinti. Nukreiptas ị esamos situacijos koregavimą, šis tyrimas negali būti sèkmingas be paties tyrèjo noro keistis, tikslingai padèti ugdytiniams ịveikti konkrečias problemas, todèl V. Koshy (2010, p. 1) pabréžia veiklos tyrimo tikslą - skatinti pati tyrẻją mokytis per savo veiklą ir siekti tiek asmeninio, tiek profesinio tobulejimo, nes veiklos tyrimas yra veiklos ir tyrimo derinys, kada asmuo, metodiškai savęs klausinėdamas, siekia suprasti, pagerinti ar keisti savo veiklą (Cohen, L., Manion, L., Morrison, K., 2013, p. 297). Tokiu būdu pedagoginès veiklos tyrimas kaip tyrimo strategija yra orientuotas ne tik i probleminiu situacijų vertinimą bei tiriamujų asmenų veiklos kokybės gerinimą, bet ir ị asmens, atliekančio tyrimą, asmeninès ir profesinès veiklos ištyrimą bei tobulinimą. Tyrimo metu pats tiriantysis turi tapti tiriamuoju ir nuolat vertinti ir reflektuoti savo veiklą: tirdamas keletą besimokančiujų ar jų grupę, analizuodamas jų veiklas ir ieškodamas būdų kilusioms problemoms spręsti, tyrëjas pats turi juos išbandyti, pritaikydamas praktiškai, vèliau, įvertinęs panaudoto būdo efektyvumą, žiūrèti, ar problema buvo išspręsta, ar buvo pasiekta geresnių veiklos rezultatų. Taigi, tyrèjas yra priverstas nuolat reflektuoti savo veiklą: apmąstyti, įvertinti savo veiklos trūkumus, keisti ir ieškoti efektyvesnių būdų ją patobulinti, jei rezultatas nelabai tenkina, vẻl grị̌ti ị ankstesni ciklą, papildyti turimus duomenis, koreguoti savo veiklą ir taip palaipsniui gilinti savo žinias ir eiti tobulejjimo link. Reflektyvumą, kuris gilina žinias bei skatina kaitą, S. Kemmis ir R. Mc Taggartas (2007, p. 282) laikè vienu iš svarbiausių veiklos tyrimo bruožų.

Šiame tyrime yra svarbūs visi dalyviai, todèl, kaip pastebi N. Bankauskienė et al (2006, p. 68), ,visada figūruoja du subjektai: pedagogas tyrejas, kuris ir tiria, ir pats tobulina, ir pats mokosi iš savo veiklos, taip pat ir ugdytinis, kuris mokosi, gauna pagalbą ir, žengdamas tobulëjimo keliu, moko savo tyrëją pedagogą bei padeda jam susivokti tobulëjimo procese“ (2006). Taigi, pedagoginès veiklos tobulinimo procesas prasideda nuo paties ugdytojo noro tobulèti, tačiau be besimokančiujju ịtraukimo ị šią veiklą jo tobulèjimas yra neịmanomas. 
Vienas iš svarbiausių veiklos tyrimo bruožų yra jo cikliškumas. Veiklos tobulinimo tyrimo cikliškumui vizualiai pavaizduoti vertètų remtis N. Bankauskienès et al (2006, p. 69) pateikta schema (žr. 1 lentelę). Iš šios schemos matyti, kad prieš pradedant kiekvieną veiklos tyrimą, pirmiausia yra identifikuojama problema ir suformuluojamas probleminis klausimas. Ši etapą L. Cohenas et al $(2007$, p. 307) laiko itin svarbiu, nes jame išsikelti ir numatyti tikslai bei uždaviniai, probleminio klausimo formulavimas gali nulemti vykdomo tyrimo sèkmę ar nesèkmę. Taip pat šiame etape N. Bankauskienè et al (2006, p. 68) pataria ištirti veiklos tyrimo aplinką, glaudžiau susipažinti su tiriamaisiais, ịvertinti tyrimo realizavimo trukmę, išspręsti etikos klausimus, atlikti su keliamos problemos specifika susijusios mokslinès literatūros analizę, numatyti būsimų metodų repertuarą (Bankauskienè, N. et al, 2006, p. 69).

Kiekvieno veiklos tyrimo svarbi sudedamoji dalis (Cohen, L. et al, 2007, p. 307) yra tyrimo ir vertinimo procedūru pasirinkimas (Cohen, L. et al, 2007, p. 307). Šiame tarpsnyje tyrejjas numato, kokia bus tyrimo imtis, kokius pasirinks medžiagos rinkimo bei tyrimo vertinimo būdus, kokius taikys mokymo ir mokymo(si) metodus, kokiu būdu bus paskirstytos užduotys ir kt. Palaipsniui pereinama prie tyrimo atlikimo.

Atliekant veiklos tyrimą, N. Bankauskienè et al (2006, p. 74) rekomenduoja „,nuolat sugrįžti prie tyrimo pradžioje suformuluoto klausimo ir ịsitikinti, ar tyrimo metu nenukrypta nuo iškeltos ir rūpimos problemos, nes atskiruose tyrimo tarpsniuose buvo keliami vis papildomi uždaviniai, ir, nepavykus pritaikyti kuri nors metodą, buvo imamasi kito, koreguojama veikla, renkami papildomi duomenys“. Atitinkamai, norint kuo nuodugniau ir plačiau suvokti tiriamajji reiškinį, reikia sukaupti kuo įvairesnių duomenų. Tuo tikslu L. Cohenas et al (2007, p. 141) pataria veiklos tyrime taikyti trianguliacijos principa - naudoti ne vieną, o du ir daugiau duomenų rinkimo būdų. Tokiu būdu yra išvengiama duomenų bei išvadų subjektyvumo ir šališkumo, yra užtikrinamas tyrimo validumas. Paskutiniu veiklos tyrimo etapu L. Cohenas et al (2007, p. 307) ịvardija duomenu interpretavima. Šiame etape tyrejjas interpretuoja duomenis, daro išvadas, vertina atliktą tyrimą, atsižvelgia i padarytas klaidas, tyrimo metu iškilusias problemas. Pateikiamas tyrimo apibendrinimas, rekomendacijos, numatoma su tyrimo rezultatais supažindinti suinteresuotus asmenis.

Apibendrinant galima teigti, kad šis tyrimas visiškai pateisina savo pavadinimą - rezultatai yra pasiekiami per aktyvią tyrèjo veiklą (angl. action) ir nuodugnią jos analizę (angl. research). Tokiu būdu veiklos tyrimo esmè yra ne tik geriau suvokti probleminę situaciją, nustatyti jos priežastis ir ieškoti būdų ją pakoreguoti, bet ir pakeisti paties pedagogo supratimą apie jo veiklą. Išmokęs reflektuoti ir kritiškai ją vertinti, pedagogas patobulès tiek asmenine, tiek profesine prasme, todèl bus linkęs praplèsti savo mokymo(si) metodų ir priemonių repertuarą, atidžiau vertinti naudojamą mokymo(si) medžiagą, taikomus metodus bei ugdymo programas. 


\subsection{Pedagoginès veiklos tobulinimo tyrimo, taikant filmus originalo kalba}

užsienio kalbų mokyme, logika, dizainas ir tiriamieji

Veiklos tobulinimo tyrimas prasideda formuluojant bendrą problemą: kokioje srityje ugdytiniams reikètų intensyviausios pagalbos. Aptariant ugdytinių lūkesčius, išryškejja situacija, kad tiriamieji yra studentai, kurie nèra mokęsi vokiečiu kalbos, bet jų motyvacija yra stipri. Tiriamieji nori girdèti natūralią kalbą, specifines komunikacines situacijas.

Tyrimas vykdytas 2016 m. vasario-balandžio mėn. Atsižvelgiant ị ugdytinių dèstomos antrosios užsienio kalbos (vokiečių) mokejjimo lygị ir socialinius poreikius, nuspręsta dirbti su mokomaja video medžiaga - filmu „EXTRA Deutsch“. Tiriamieji atrinkti patogiosios imties principu. Tiriamujų imtis - 23 studentai (n-23).

Tiriamieji prieš tai nesimokẻ vokiečių kalbos arba ją mokejjo minimaliai. Tiriamieji - $23 \mathrm{X}$ universiteto studentai. Amžius - 20-21 metai. Iš viso grupejje yra 12 vaikinų ir 11 merginų.

Vokiečių kalbos paskaitos anglų kalba vyksta 2-3 kartus per savaitę po 1,5 val. Besimokančiujų grupė yra multikultūrinè. Nors dauguma studentų yra lietuviai, 21,7 proc. - užsieniečiai. Grupès dalyvių kilmės šalys - Lietuva, Italija, Taivanas, Turkija. Vokiečių kalbos lygis - pradedantieji (pagal Europos kalbų matmenis - A1.1).

Tyrime dalyvaujantiems studentams buvo pateiktas mokomasis serialas „Extra“. Tai - situacijų komedija, skirta kalbų mokymuisi. Iš viso yra 13 serijų. Filmą galima žiūrèti vokiečių, anglų, prancūzų ir ispanų kalbomis. Kalbos supratimo įtvirtinimui yra pateikti ịvairūs žodyno, gramatikos, kalbẻjimo pratimai.

Tyrimo metu studentams buvo keliama užduotis sinchroniškai versti girdimą tekstą iš vokiečių kalbos ị anglų kalbą, o po to pateikti vertimo variantą raštu. Respondentams reikejjo reflektuoti vertimo sèkmę ir iškilusias problemas.

Dirbant su filmu originalo kalba, verta akcentuoti veiklos tobulinimo tyrimui svarbius metodinius žingsnius (žr. 1 lentelę). 
1 lentelè. Veiklos tobulinimo tyrimo metodiniai žingsniai, dirbant su filmu originalo kalba

\begin{tabular}{|c|c|}
\hline $\begin{array}{l}\text { Pirmasis žingsnis: } \\
\text { tiriamosios grupès } \\
\text { charakteristika }\end{array}$ & $\begin{array}{l}\text { Būdinga veikla: prieš parenkant filmą, reikètų atsižvelgti ị tikslinę grupę } \\
\text { (koks amžius, kalbos lygis, ar moka kitų užsienio kalbų, kokie yra } \\
\text { besimokančiųu pomėgiai, kultūriniai asmenybių skirtumai). Gaunami } \\
\text { besimokančiujų sutikimai dalyvauti pedagoginès veiklos tobulinimo tyrime. }\end{array}$ \\
\hline $\begin{array}{l}\text { Antrasis žingsnis: } \\
\text { ugdomų gebejjimų } \\
\text { prioritetų } \\
\text { parinkimas }\end{array}$ & $\begin{array}{l}\text { Būdinga veikla: apsisprendžiame, ką akcentuosime: } \\
\text { turimas gramatikos, žodyno žinias ar mokymo plane numatytą temą. }\end{array}$ \\
\hline $\begin{array}{l}\text { Trečiasis žingsnis: } \\
\text { filmo turinio } \\
\text { parinkimas, } \\
\text { atsižvelgiant } \mathfrak{i} \\
\text { pirmojo ir antrojo } \\
\text { žingsnio rezultatus }\end{array}$ & $\begin{array}{l}\text { Būdinga veikla: vertinamas atrenkamo filmo turinys, atsižvelgiant ị tai, } \\
\text { kaip jis siejasi su tikslinės grupės vizija, skatina diskutuoti, plečia krašto } \\
\text { pažinimo, tarpkultūrines žinias, ar yra autentiškas - pavaizduotos tikros } \\
\text { gyvenimiškos situacijos, ar vaidina aktoriai, kalbantys gimtaja kalba). }\end{array}$ \\
\hline $\begin{array}{l}\text { Ketvirtasis } \\
\text { žingsnis: } \\
\text { metodinio } \\
\text { repertuaro } \\
\text { formavimas }\end{array}$ & $\begin{array}{l}\text { Būdinga veikla: dirbant su šia konkrečia tiriamųjų grupe, buvo } \\
\text { orientuojamasi ị komunikacinei kalbos mokymosi krypčiai būdingus metodus: } \\
\text { skatinamas dialogas, naudojant aktualų žodyną, atliekami filmo turinio } \\
\text { inspiruoti vaidmenys, inicijuojama trumpa diskusija. Siekiant, kad dèmesys } \\
\text { būtų nepertraukiamas ir pastebimos detalès, rekomenduojamos tokios užduotys } \\
\text { kaip teisingi/klaidingi teiginiai, ,irašomas praleistas žodis ir t. t.). } \\
\text { Aptariami gramatiniai sunkumai. }\end{array}$ \\
\hline $\begin{array}{l}\text { Penktasis } \\
\text { žingsnis: } \\
\text { paskaitos refleksija }\end{array}$ & $\begin{array}{c}\text { Būdinga veikla: besimokantieji reflektuoja savo rezultatus, } \\
\text { akcentuodami padarytą pažangą, diagnozuodami, } \\
\text { kodèl jiems pavyko geriau atlikti duotas užduotis. }\end{array}$ \\
\hline
\end{tabular}

Atlikus pilotinę studentų refleksijų analizę, išryškẻja besimokančiųjų antrosios užsienio kalbos metodų prioritetai. Studentai akcentavo, kad motyvuojančios kalbėti užduotys yra: vaizdo be garso žiūrèjimas/garso be vaizdo klausymasis, kuriant savas stebimo ar girdimo įvykio versijas, subtitrų rašymas; scenos vaidinimas; išmaišyto scenarijaus dèliojimas iš eilès; istorijos tęsinio kūrimas. Besimokantieji taip pat teigiamai vertino filmo dalių vertimą.

Daug moderniosios pedagogikos praktikų abejoja vertimo metodu, tačiau jis vis dar populiarus iki šių dienų. Šiandien vertimas suprantamas kaip tikslinga komunikacinè veikla (Pöchhacker, F., 2017). Jam taikomi įvairūs apibūdinimai, tokie kaip prose translation (vertimas ị užsienio kalbą) ir version (vertimas i gimtają kalbą) arba direct (vertimas ị gimtają kalbą) ir inverse (vertimas ị užsienio kalbą). Užsienio kalbų mokyme skirtingos vertimo kryptys siekia skirtingų mokymo tikslų, pavyzdžiui, atitinkamo frazių vertimo ir stilistinès elegancijos, verčiant i gimtają kalbą, ar gramatinių struktūrų mokymosi, verčiant ị užsienio kalbą (Kittel, C., 2004). 


\section{Studentụ požiūriụ ị filmụ originalo kalba naudojimo efektyvumą, mokantis vokiečių kalbos angliškai, turinio analizė}

Studentų požiūris į filmų originalo kalba galimybes, mokantis antrosios užsienio kalbos (vokiečių), komunikuojant angliškai, buvo tiriamas fenomenografinès turinio analizès principu.

Tyrimo situacijos aprašymas. Rengiantis tyrimui, paaiškejjo, kad 70 proc. apklaustujų neturejo užsienio kalbos mokymosi, žiūrint filmus originalo kalba, patirties. Juos žiūri tik savarankiškai anglų arba gimtaja kalbomis. Grupé geba suprasti ir vartoti žinomus būtiniausius posakius ir pagrindines frazes, kad patenkintų konkrečius poreikius. Besimokantieji geba prisistatyti ir pristatyti kitą, užduoti asmeninio pobūdžio klausimus (pavyzdžiui, kur gyvena, ką pažista, kokius daiktus turi) ir atsakyti į tokius pat klausimus. Studentai gali susikalbèti labai paprastai, jei pašnekovas kalba lètai, aiškiai ir yra pasirengęs padèti dalyvauti interakcijoje. Kadangi mokymo medžiagos aktualizavimas siejamas su besimokančiųu patirtimi, interesais, poreikiais, tiriamujų buvo klausta, ar pageidautų i kalbos mokymosi procesą itraukti filmus ir su jais susijusias užduotis (Kalvaitis, A., 2014) - 92 proc. atsakè teigiamai, 6 proc. abejojo.

Metodinès veiklos buvo organizuojamos, siekiant optimizuoti turinio supratimo ir dalyvavimo interakcijoje procesus. Pirmiausia su studentais paskaitu metu be išankstinio pasiruošimo buvo žiūrima viena serija be subtitrų, kurios trukmè apie 25 min., po to detaliai išsiaiškinamas turinio ir atpažintų gramatinių struktūrų supratimo lygis. Namų darbų užduotis - išversti subtitrus/dialogus ị anglų kalbą ir tokiu būdu susipažinti su žodynu, panagrinèti gramatines struktūras, ịtvirtinant paskaitos metu ịgytas žinias.

Svarbiausia tyrimo dalis - filmo originalo kalba efektyvumo diagnostika buvo tiriama uždavus studentams klausimą: „Kaip vertinate vokiečių kalbos mokymąsi, žiūrèdami filmus originalo kalba? Pagrịskite savo atsakymą, nurodydami savo sèkmes ir nesèkmes, mokantis vokiečių kalbos."

Remiantis fenomenografinès turinio analizès principais, kuriama kokybinių kategorijų sistema. Ši sistema turètų padèti įvertinti studentų patirties aspektus, mokantis antrosios užsienio kalbos (vokiečių) komunikuojant angliškai, kai mokomasi iš kino filmų originalo kalba. Studentų atsakymai skirstomi ị reikšminius vienetus, kai grupuojami tiriamujų komentarai išplètoja atskirą prasmès kategoriją, kol ši tampa homogeniška. Toliau kiekvienos kategorijos citatos grupuojamos ị subkategorijas pagal žodžių-raktų principą. Skirstant citatas ị subkategorijas, išryškèjo tyrimo ribotumai: kadangi klausime buvo koduojamas teigiamos/neigiamos patirties dvipoliškumas, studentų atsakymai taip pat pasiskirstė ị dvi kokybines kategorijas. Tai šiek tiek apribojo studentų patirties raiškos turinį, tačiau sudare galimybes smulkiau išanalizuoti teigiamos ir neigiamos patirties aspektus. Tokiu būdu pirmajai kokybinei kategorijai „Mokymosi vokiečių kalbos, žiūrint filmus originalo kalba, teigiama patirtis“" priklauso visos subkategorijos, ịvardijančios visas teigiamas pa- 
tirtis (180 citatu). Antrajai kokybinei kategorijai priskiriamos visos subkategorijos, kurios nurodo neigiamas vokiečių kalbos mokymosi, žiūrint filmus ir komunikuojant angliškai, patirtis (157 citatos). Studentų atsakymus sugrupavus ị kokybines temines kategorijas, kategorijos koduojamos ir pateikiama jų statistinè raiška. Iš viso užfiksuotos 337 citatos. Pirmojoje kokybinèje kategorijoje „Mokymosi vokiečių kaip antrosios užsienio kalbos, žiūrint filmus originalo kalba, teigiama patirtis“ galima išskirti penkias subkategorijas, akcentuojančias įvairias kalbos mokymosi veiklų teigiamas patirtis.

2 lentelè. Kokybinès kategorijos „Mokymosi vokiečiu kalbos, žiūrint filmus originalo kalba, teigiama patirtis“" subkategorijų raiška

\begin{tabular}{|c|c|c|c|c|}
\hline $\mathrm{Nr}$. & Kokybinė kategorija & Subkategorija & Citata & $\begin{array}{c}\text { Citatų } \\
\text { skaičius }\end{array}$ \\
\hline \multirow[t]{5}{*}{1.} & $\begin{array}{l}\text { Mokymosi vokiečiu kalbos, } \\
\text { žiūrint filmus originalo kalba, } \\
\text { teigiama patirtis }\end{array}$ & $\begin{array}{l}\text { 1.1. Atminties } \\
\text { lavinimas }\end{array}$ & $\begin{array}{l}\text { „<...> lengviau įsiminti, kai } \\
\text { frazè siejama su vaizdu ir } \\
\text { garsu...“ }\end{array}$ & 65 \\
\hline & & $\begin{array}{l}\text { 1.2. Klausymo } \\
\text { gebejjimų lavinimas }\end{array}$ & 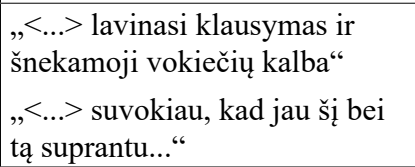 & 48 \\
\hline & & $\begin{array}{l}\text { 1.3. Kalbejjimo } \\
\text { emancipavimas }\end{array}$ & $\begin{array}{l}\text { „<..> naudingi kasdieniai } \\
\text { žodžiai, frazès; lavinasi } \\
\text { tarimas..." }\end{array}$ & 38 \\
\hline & & $\begin{array}{l}\text { 1.4. Gramatikos } \\
\text { taisyklių supratimas }\end{array}$ & 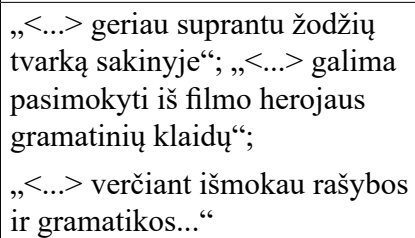 & 18 \\
\hline & & $\begin{array}{l}\text { 1.5. Lyginamosios } \\
\text { kalbotyros } \\
\text { pradmenu } \\
\text { formavimasis }\end{array}$ & $\begin{array}{l}, \ldots \ldots>\text { radau sąsajų tarp anglų } \\
\text { ir vokiečių kalbų, o tai padeda } \\
\text { lengviau suprasti ir išmokti } \\
\text { vokiečių kalbą; taip įdomiau } \\
\text { mokytis..." }\end{array}$ & 11 \\
\hline
\end{tabular}

Faulstichas (2002), pabrèždamas medijų, o ypač filmų efektyvumą, mokantis užsienio kalbų, ypatingą dėmesị atkreipia ị vizualizacijos galimybes, suvokiant ir ịsimenant tekstą. Analogiškus prioritetus akcentuoja ir studentai. Pati gausiausia kokybinė subkategorija yra „Atminties lavinimas“, kurios turinyje išryškèja vienas iš pagrindinių filmų taikymo užsienio kalbų mokymesi metodinių privalumų regimosios ir girdimosios atminties lavinimo dermè: „< ..> lengviau ịsiminti, kai frazė siejama su vaizdu ir garsu...“. Pagal Blellą, Leutgę (2008), filmų originalo kalba efektyvumą, mokantis užsienio kalbos, nulemia filmų interakcijos ugdymo galimybès, vizualiai pateikiamo teksto autentiškumas. Ši požiūrị patvirtina antroji teigiamą patirtị atskleidžiančios kategorijos subkategorija „,Klausymo gebejjimų la- 
vinimas“. Studentai akcentuoja faktą, kad sudaromos sąlygos aktyviam klausymui: „<..> lavinasi klausymas ir šnekamoji vokiečių kalba...". Akcentuojant kalbèjimo emancipavimo aspektą (Čiučiulkienè, N., 2004), verta atkreipti dèmesị ị kartu su studentais vykdomo pedagoginès veiklos tyrimo specifiką, pabrèžiant jo cikliškumą, kryptingumą, diskusijos ịgalinimą (Kemmi, S., Mc Taggart, R., 2007). Studentai taip pat teigia, kad buvo gilinama komunikacinè kompetencija, intensyviai plètojamas aktyvus žodynas: „, $<$..> dialoguose naudojami naudingi kasdieniai žodžiai, frazės...". Taip pat aktyviai praktikuojamas tarimo ir gramatinių modelių įsisavinimas: „<...> lavinasi tarimas; galima pakartoti/įtvirtinti žinias; geriau suprantu žodžių tvarką sakinyje; galima pasimokyti iš filmo herojaus gramatinių klaidų; verčiant išmokau rašybos ir gramatikos; suvokiau, kad jau ši bei tą suprantu; radau sąsajų tarp anglų ir vokiečių kalbų...”. Apibendrinant galima teigti, kad užsienio kalbų mokymasis, naudojant filmus originalo kalba, paverčia didaktinị procesą malonia kūrybine veikla: „, $<\ldots>$ tai padeda lengviau suprasti ir išmokti vokiečių kalbą; taip įdomiau mokytis..."

Vokiečių kalbos kaip antrosios užsienio kalbos sunkumai atskleidžiami antroje kokybinėje kategorijoje, kurią sudaro dvi subkategorijos (žr. 3 lentelę ).

3 lentelè. Kokybinès kategorijos „Mokymosi vokiečių kaip antrosios užsienio kalbos, žiūrint filmus originalo kalba, sunkumai" subkategorijų raiška

\begin{tabular}{|c|c|l|l|c|}
\hline Nr. & \multicolumn{1}{|c|}{ Kokybinè kategorija } & Subkategorija & Citata & $\begin{array}{c}\text { Citatu } \\
\text { skaičius }\end{array}$ \\
\hline 1. & $\begin{array}{l}\text { Vokiečių kaip antrosios } \\
\text { užsienio kalbos mokymasis, } \\
\text { žiūrint filmus originalo kalba }\end{array}$ & $\begin{array}{l}\text { 2.1. Klausymo } \\
\text { gebėjimų stoka }\end{array}$ & „<...> ne viską pavyko išgirsti...“ & 83 \\
\hline & & $\begin{array}{l}\text { 2.2. Aktyvaus } \\
\text { žodyno apimties } \\
\text { problemos }\end{array}$ & $\begin{array}{l}\text { „<..> sunku buvo suprasti ir išversti } \\
\text { kai kuriuos posakius/frazes...“ }\end{array}$ & 74 \\
\hline
\end{tabular}

3 lenteleje pateiktos subkategorijos atskleidžia tradicinius antrosios užsienio kalbos mokymosi sunkumus. Tai - klausymo ir teksto supratimo problematika (83 citatos), žodyno plètros sunkumai (74 citatos). Studentai teigia, kad „, <..> ne viską pavyko išgirsti; sunku buvo suprasti ir išversti kai kuriuos posakius/frazes...". Lyginant abi kokybines kategorijas, akivaizdu, kad pirmojoje kategorijoje eksplikuojama daugiau kokybinių subkategorijų, kurios komunikuoja teigiamas patirtis. Netgi tokios neigiamos subkategorijos kaip 2.1. „Klausymo gebejimų stoka“ perspektyvoje turètų būti pakankamai greitai įveikiamos, nes patys respondentai teigia, kad ,$<\ldots$..> lavinasi klausymas ir šnekamoji vokiečių kalba“; , „<...> suvokiau, kad jau ši bei tą suprantu“. 


\section{Išvados}

1. Atlikus sampratų „,europinis raštingumas“, „filmų originalo kalba naudojimas kaip metodas" mokslinès literatūros analizę, galima tvirtinti, kad raštingumas siejamas su mokymo ir mokymosi socialinès ir technologinès aplinkos kaita. Jam įtaką daro socialiniai pokyčiai ir greitas komunikacinių technologijų vystymasis, todèl šiandienos mokytojui/dèstytojui siekiant išlikti moderniam, jis skatinamas pasitelkti pamokose/paskaitose televiziją ar internetą ir mokymo veikloje naudoti originalius šaltinius.

2. Siekiant pagrịsti filmų originalo kalba naudojimo efektyvumą, buvo atliktas Pedagoginès veiklos tobulinimo tyrimas, kuris padejo suvokti probleminę situaciją - kaip lavinti komunikacinius gebejjimus, nustatyti probleminès situacijos priežastis ir ieškoti būdų ją pakoreguoti bei pakeisti paties pedagogo supratimą apie jo veiklą.

3. Apibendrinant studentu apklausą ir gautus rezultatus, galima teigti, kad vokiečių kalbos kaip antrosios kalbos mokymasis, žiūrint filmus originalo kalba, yra perspektyvus, padedantis efektyviai mokytis užsienio kalbos metodas.

\section{Literatūra}

1. Ambrasè, N. (2012). Pedagogo veiklos tobulinimas: vaikų globos namų auklètinių rengimas šeimai. Kaunas: Technologija.

2. Altrichter, H. (1990). Ist das noch Wissenschaft? Darstellung und wissenschaftstheoretische Diskussion einer von Lehrern betriebenen Aktionsforschung. München.

3. Altrichter, H., Posch, P. (2007). Lehrerinnen und Lehrer erforschen ihren Unterricht. Unterrichtsentwicklung und Unterrichtsevaluation durch Aktionsforschung, Bad Heilbrunn.

4. Augustinienè, A., Čiučiulkienè, N. Reverse Mentoring as Facilitating Factor for the Development of a Beginning Teacher's Self-authorship Process // Social Sciences $=$ Socialiniai mokslai / Kaunas University of Technology. Kaunas: KTU. ISSN 1392-0758. 2013, Nr. 3(81).

5. Augutis, P. (1996). Pedagoginès sąvokos ir mokymo proceso valdymo aspektai pamokoje. Šiauliai.

6. Bankauskaitè-Sereikienè, G., Augustinienè, A. (2007). Pedagogo veiklos tobulinimas: pagalba VI klasès mokiniams mokytis priebalsių rašybos: mokslo studija. Kaunas: Technologija.

7. Bankauskienè, N., Čiužas, R., Trofimova, R. (2012). Pedagogo veiklos tobulinimas: pagalba skleistis VI klasès mokinių kūrybiškumui dailès pamokose. Kaunas: Technologija.

8. Bankauskienè, N. (2012). Pedagogo veiklos tobulinimas: pagalba skleistis VI klasès mokinių kūrybiškumui dailès pamokose. Kaunas: Technologija. 
9. Bankauskienė, N., Čiužas, R., Trofimova, R. (2010). Pedagogo veiklos tobulinimas: pagalba $\mathrm{V}$ klasès mokiniams rengti tekstinius dokumentus taikant informacines technologijas. Kaunas: Technologija.

10. Bergfelder-Boss, G. (2011-2012). Theorie-Praxis-Modul II: Aktionsforschung für Weiterbildungsstudierende. Internetinè versija: http://www.geisteswissenschaften.fu-berlin.de Žiūrèta: 2016-10.

11. Bewertungstabelle. Internetine versija: http://www.unterrichtsdiagnostik. info. Žiūrèta: 2016-02.

12. Bitinas, B., Rupšienė, L., Žydžiūnaitè, V. (2008). Kokybinių tyrimų metodologija. Klaipèda.

13. Boeckmann, K. B., Feigl-Bogenreiter, E., Reininger-Stressler, D. (2010). Forschendes Lehren. Aktionsforschung im Fremdsprachenunterricht. Verband Österreichischer Volkshochschulen.

14. Chlosta, Ch., Leder, G., Krischer, B. (2008). Auf neuen Wegen - Deutsch als Fremdsprache in Forschung und Praxis, Göttingen.

15. Cohen, A. D. (2014). Strategies in Learning and Using a Second Language. Routledge.

16. Cohen, L., Manion, L., Morrison, K. (2013). Research Methods in Education. Routledge.

17. Cremin, T. (2015). Teaching English Creatively. Routledge.

18. Čiučiulkienè, N., (2004). Probleminio mokymosi samprata ir reikšmè aukštajam mokslui. Disertacija. Internetinè versija: http://vddb.laba.lt/fedora/get/ LT-eLABa-0001:B.03 2011 ISBN_978-609-430-085-1/DS.001.0.01.BOOK. Žiūrèta: 2016-01.

19. Gage, N. L., Berlinger, D. C. (1994). Pedagoginè psichologija. Vilnius: Alma litera.

20. Gelūnas, A. (2015). Multilingualism as a Prerequisite of Intercultural Education: From UNESCO Programmes to Sustainable Development Challenges of Modern States. Sustainable Multilingualism, (6), p. 16-23.

21. Gläser-Zikuda, M., (2007). Lehramtstudierende reflektieren und evaluieren ihr Unterrichtshandeln - zum Potenzial des Tagebuch-Ansatzes, VS Verlag für Sozialwissenschaften.

22. Guldimann, T., (2003). Internetinė versija: http://methodenpool.uni-koeln. de/tagebuch/begruendung.html Žiūrèta: 2016-03.

23. Hahn, N. (2015). Filmbildung im deutschdidaktischen und im DaF-didaktischen Handlungsfeld: eine kontrastive Perspektive. In: Welke, Tina; Faistauer, Renate (Hrsg.) (2015): Film im DaF/DaZ-Unterricht. Beiträge der XV. IDTBozen. Wien: Praesens-Verlag, p. 13-38.

24. Hahn, N., Schöler, M. (2013). Mit Scaffolding zur Fachsprache Film im DaF-Unterricht. In: Info DaF, 6, S. 584-621.

25. Henecka, H. P. (1999). Methoden der Sozialwissenschaften. Internetinè versija: http://www.sowi-online.de/praxis/methode/methoden_sozialwissenschaf- 
ten.html Žiūrèta: 2016-03.

26. Jovaiša, L. (2007). Enciklopedinis edukologijos žodynas. Vilnius.

27. Jusienė, R., Laurinavičius, A. (2007). Psichologija. Vilnius: Mykolo Romerio universiteto leidybos centras.

28. Faulstich, W. (2002).Grundkurs Filmanalyse. München: Wilhelm Fink Verlag.

29. Nünning, A., Surkamp, C. (2006). Englische Literatur unterrichten. Seelze-Velber: Klett/Kallmeyer.

30. Kalvaitis, A. (2014). Vadovèlị papildančiu mokymo priemonių naudojimo tendencijos Lietuvos bendrojo ugdymo mokyklų pamokose, Acta paedagogica Vilnensia, 2014 32:155.

31. Kniffka, G. (2010). Scaffolding. ProDaZ. Deutsch als Zweitsprache in allen Fächern. Stiftung Mercator. (www.uni-due.de/prodaz/konzept.php) (2014-07-22).

32. Koch, P., Oesterreicher, W. (1994). Schriftlichkeit und Sprache. In: Günther, Hartmut; Otto, Ludwig (Hrsg.): Schrift und Schriftlichkeit. Writing and Its Use. Ein interdisziplinäres Handbuch internationaler Forschung. An Interdisciplinary Handbook of International Research. Berlin und New York: 587-604. (=Handbücher zur Sprach- und Kommunikationswissenschaft 10.1).

33. Leonavičienè, V., Salienė, V. (2013). Žmogus ir žodis I „Inovatyvūs kalbų mokymo(si) metodai šiuolaikiniame ugdymo kontekste“ p. 139-143.

34. Levin, K., Graumann, C. F. (1981). Wissenschafttheorie, Klett-Cotta.

35. Meyer, J. (2006). Qualitative Research in Health Care, Third Edition, Blackwell Publishing Ltd.

36. Ohm, U. (2010). Fachsprache. In: Barkowski, Hans; Krumm, Hans-Jürgen (Hrsg.): Fachlexikon Deutsch als Fremd- und Zweitsprache. Tübingen/Basel: A. Francke Verlag, S. 75.

37. Peterson, S. S., Heywood, D. (2007). Contributions of Families' Linguistic, Social, and Cultural Capital to Minority-Language Children's Literacy: Parents', Teachers', and Principals' Perspectives. Canadian Modern Language Review, 63(4), 517-538.

38. Pöchhacker, F. (2017). Simultaneous Interpreting: A Functionalist Perspective. HERMES-Journal of Language and Communication in Business, 8(14), 31-53.

39. Rajeckas, V. (1999). Mokymo organizavimas. Kaunas: Šviesa.

40. Ramonienè, M. (2014). Kalbų vartojimas darbe didžiuosiuose Lietuvos miestuose. Lietuviu kalba, (5).

41. Rehm, G., Uszkoreit, H., Dagan, I., Goetcherian, V., Dogan, M. U., Mermer, C., Oeter, S. (2014). An Update and Extension of the META-NET Study "Europe's Languages in the Digital Age". Proceedings of the Workshop on Collaboration and Computing for Under-Resourced Languages in the Linked OpenData Era. 
42. Rowsell, J. (2013). Working with Multimodality: Rethinking Literacy in a Digital Age. Routledge.

43. Schoroškienè, V., Bacevičienè, A. (2011). Informacinių tekstų skaitymo gebejjimų ugdymas pradinèse klasèse//Pasaulis vaikui: ugdymo realijos ir perspektyvos (tęstinis mokslo straipsnių leidinys, 4 tomas). Edukologija (ISBN 9789955207160).

44. Staskevičienè, V., Bankauskienè, N. (2012). Pedagoginès veiklos tobulinimas: darbas su globojamu vaiku ir jo šeima. Kaunas: Technologija.

45. Stiletto, S. (2012). Methoden der Filmarbeit. Herausgegeben von der Bundeszentrale für politische Bildung und Vision Kino. (www.kinofenster.de/lehrmaterial/methoden) (2014-07-30).

46. Thaler, E. (2010). Filmdidaktik. In: Hallet, Wolfgang; Königs, Frank G. (Hrsg.): Handbuch Fremdsprachendidaktik. Seelze-Velber: Klett/Kallmeyer, p. 142-146.

47. Vaišnienè, D., Zabarskaite, J., Rehm, G., Uszkoreit, H. (2012). The Lithuanian Language in the Digital Age. Springer.

48. Walczak-Niewiadomska, A. (2015). Sprawozdanie z 19th European Conference on Literacy 13-16 lipca 2015, Klagenfurt, Austria. Acta Universitatis Lodziensis. Folia Librorum, (Acta Universitatis Lodziensis. Folia Librorum nr 21/2015). 


\title{
EDUCATIONALVISTAOFACTIONRESEARCHWHILETEACHING GERMAN IN ENGLISH: THE ASPECT OF FEATURE FILM USE
}

\author{
Assoc. Prof. Dr. Nijolė Čiučiulkienė \\ Aleksandras Stulginskis University
}

Jurgita Lukienė

Kaunas University of Technology; Erfurt University, Phd student

\section{Summary}

The European Commission actively promotes linguistic diversity. In addition to their native languages, European citizens should be able to communicate in at least two foreign languages (Gelūnas, 2015; Walczak-Niewiadomska, 2015). Moreover, globalization processes bring to language classes such innovations like teaching a second foreign language (German) using English as lingua franca. This idea brings a challenge to a foreign language teacher, because in order to be effective, teachers have to expand their roles, change training/teaching methods and the content of curriculum material. For this reason, it is particularly important to provide interesting, relevant and motivating material which would enable learners make their learning German active, promote their improvement not only in German but in English as well and develop individual learning and self-assessment skills (Leonaviciene, Saliene, 2013). To monitor all these processes, teachers should be not only educators but researchers as well.

Action research is a powerful tool for changing and improving both teaching and learning partners: a teacher and a student. The methodological scope of the action research is impressive. It can be used in almost any setting where a problem, tasks and procedures cry out for mutual solution of a teacher and a learner (Cohen, Manion, Morrison, 2007).

After fulfilling a diagnostic stage of the action research that analyzed students' language acquisition level and their expectations about learning German as a second language, the authors of this research paper have chosen the method of applying movies in the original language. This method is analyzed by many authors (Blell, Leutge, 2008). The action research question was how to help English students to improve their German speaking skills while watching movies. This question implied such activities as listening comprehension, interpretation, subtitling, and independent sound recording.

At the end of the action research, the following advantages of the method were revealed: students stated that they improved not only German but English as well; it was easier to memorize vocabulary when watching movies in original (German) language and comparing it to English when a phrase was associated with 
an image and sound and to develop listening and speaking skills. Weak points were highlighted as well: students were not able to hear everything and it was difficult to understand and translate idioms.

Keywords: learning second foreign language in English, information technologies, movie in original language, foreign language teaching and learning, translation

\section{AUTORIŲ LYDRAŠTIS}

Autoriaus vardas, pavardė: Nijolè Čiučiulkienė

Mokslo laipsnis ir vardas: socialinių mokslų daktarè, docentė

Darbo vieta ir pareigos: Aleksandro Stulginskio universiteto Filosofijos, psichologijos ir profesinès edukologijos katedra

Autoriaus mokslinių interesų sritys: komunikavimo emancipavimas, mokytojų rengimas, mentorystė/reversinė mentorystè, probleminis mokymasis (PBL)

Telefonas ir el. pašto adresas: nijole.ciuciulkiene@asu.lt

Autoriaus vardas, pavardė: Jurgita Lukienè

Darbo vieta ir pareigos: Kauno technologijos universiteto lektore Autoriaus mokslinių interesų sritys: pedagogika, lingvistika

Telefonas ir el. pašto adresas: jurgita.lukiene@ktu.lt

\section{AUTHORS' COVER LETTERS}

Author's name and surname: Nijolė Čiučiulkienė

Academic degree and name: Doctor of Social Sciences, Associate Professor Workplace and position: Aleksandras Stulginskis University, Department of Philosophy, Psychology and Vocational Education

Author's research interests: emancipation of communicating, teacher training, mentoring/reverse mentoring, problem-based learning

Telephone and e-mail address: nijole.ciuciulkiene@asu.lt

Author's name and surname: Jurgita Lukienè

Workplace and position: Kaunas University of Technology, Department of Intercultural Communication and Modern Languages, Lecturer

Author's research interests: pedagogy, linguistics

Telephone and e-mail address: jurgita.lukiene@ktu.lt 